\title{
EFFECTS OF PYROGENIC FACTOR ON WETLANDS OF PETROVSKAYA PAD' (JEWISH AUTONOMOUS REGION, RUSSIA)
}

\author{
Tatyana A. Kopoteva, Victoria A. Kuptsova \\ Institute of Water and Ecology Problems FEB RAS, Russia \\ e-mail: kopoteva@ivep.as.khb.ru,victoria@ivep.as.khb.ru
}

Received: 26.11.2018. Revised: 19.03.2019. Accepted: 23.04.2019.

\begin{abstract}
In recent decades, a severe wildfire situation threatening the territory along the periphery of the Bastak State Nature Reserve (Russia) has developed in the Petrovskaya Pad'. In this paper, we assessed the current state of the vegetation cover and post-pyrogenic changes in the Petrovskaya Pad', based on the geobotanical survey during a joint expedition in 2009. At present, this area of the Middle Amur Lowland is a vivid example of wetland degradation due to the repeated wildfire impact initiated by the local people and agricultural workers in the Amur region. The widespread xerophytisation process of fen vegetation, due to a sharp drop in the groundwater level, was observed. A comparison with the data of previous studies led to the conclusions that now mesotrophic shrubSphagnum bogs, described earlier, have completely disappeared from the vegetation cover of the territory. We suggest that their degradation is caused by the continuously acting pyrogenic factor. In addition, the paper for the first time provides data on the dynamics of the acrotelm structure in the post-pyrogenic period, which were obtained during a nine-year monitoring. The profound changes in the acrotelm structure are responsible for the restoration of mesotrophic bogs taking decades.
\end{abstract}

Key words: acrotelm, biodiversity, mires, pyrogenic subclimax, uncontrolled fire

\section{Introduction}

The waterlogged area of the Middle Amur Lowland is approximately 50\% (Prozorov et al., 1970). This is a landscape complex of mire ecosystems of eutrophic and mesotrophic types interspersed with forested hummocks. About half of the main territory of the State Nature Reserve «Bastak» (hereafter also - Bastak Reserve) is located in the southwestern part of the lowland. The plain part of the Bastak Reserve is heavily waterlogged. Among the mires, grass-Hypnum and Carex fens, and transitional dwarf-shrub-Sphagnum ones predominate. The monsoon character of precipitation leads to prolonged excessive soil moisture, winters with low snowfall, long-term preservation of seasonal frozen soil and deep freezing of the soil (150-200 $\mathrm{cm}$ ), while poor permeability of clay soils contributes to the widespread occurrence of mires. Periods of heavy monsoon rains are often interchanged with long summer droughts. Because of this, brush fires here are very common. Prozorov (1985) considered this factor to be one of the main causes of thin peat deposits in the mires of the Middle Amur Lowland despite their old age. Peat deposit in the River Kiya basin has been dated to 9000 cal BP and that in the River Gur basin to 10 000-14 000 cal BP (Bazarova et al., 2018).

This part of the Jewish Autonomous Region was developed among the first in the region and has been used as an agricultural area since the beginning of the $20^{\text {th }}$ century. Traditionally, spring burning of the grass has been carried out as one of the agricultural practices generally accepted here. It usually turns into annual uncontrolled fires throughout the territory. In modern times, the fires have become a continuously acting factor affecting the extent and dynamics of forest and bog formation processes. A severe pyrogenic situation leading to alteration and depletion of vegetation cover has developed on the periphery of the Bastak Reserve. For this reason, in 2011 the Bastak Reserve administration established the cluster area «Zabelovsky» with the financial support of the Amur Branch of the World Wildlife Fund. The issue of assigning the status of the Protected Area to the Petrovskaya Pad' was rising many times. By that time, the landscapes of the Petrovskaya Pad', located between the Bastak Reserve and its cluster, had been already considered as an area with complete loss of their ecological functions (Kalinin, 2009). A local newspaper wrote: «The vast area of Petrovskaya Pad' has been famous for a wealth of flora and fauna only about three decades ago. Now there is little evidence of its former richness. Annual wildfires have not only destroyed a significant part of it, but also dried up all its water resources. It is clear that aquatic and riverside animals inhabited it had left the degraded zone. Having previously been swampy and impassable, Petrovskaya Pad' became literally dried up and covered with hard, dwarf and barren shrubs. 
Members of the expedition of environmental scientists from Khabarovsk and Birobidzhan, visited Petrovskaya Pad' a few years ago, accurately noticed that it is possible to ride a bicycle here... And it entered such a state as soon as people stopped fighting fires here... (These priceless mires, 2015).

Profound changes in vegetation of the waterlogged areas of the Middle Amur Lowland, especially those that have undergone the earliest economic development, occur under the influence of the pyrogenic factor (Kopoteva, 2009). Because of frequently repeated fires, the vegetation cover of bogs in the Amur region is transformed into birch (Betula ovalifolia Rupr.) thickets devoid of Sphagnum cover (so-called «yerniki») (Kopoteva, 1999; Burenina, 2006). About $50-70 \%$ of the areas, previously occupied by dwarf-shrub-Sphagnum bogs with open larch stand (so-called «mari»), were transformed into Sphagnum-free yerniki in relatively densely populated areas in the south of the Khabarovsky Krai and in the Amur region.

The main biosphere function of the bogs (carbon deposition) is believed to be provided by Sphagnum mosses (Vitt, 2000; Benscoter \& Vitt, 2008; Kosykh et al., 2009). They play primary a coenotic and peat-forming role in mires of this type. Among all the components of vegetation, the mosses make the largest contribution to carbon sequestration. By the end of the second year, over $90 \%$ of the production of all vascular plants in Sphagnum bogs is mineralised (Vishnyakova et al., 2012). At the same time, Sphagnum fuscum (Schimp.) H. Klinggr., predominated in the moss cover of the mesotrophic mires of the Amur region, decomposes only by $20 \%$ of the initial mass by the end of the first year and by another $10 \%$ two years later (Kozlovskaya et al., 1978; Germanova, 1983; Rochefort et al., 1990). The phytocoenoses are similar in vegetation structure to the mires of the Middle Amur Lowland. Studies of their productivity showed that the annual production of the moss layer $(62 \%)$ is almost twice as much as the production of tree and herb-dwarf-shrub layers combined (38\%) (Pyavchenko, 1967), and 3-4 times higher than the annual production of aboveground parts of plants of the same layers (Kopoteva, 1993; Knorre et al., 2007). Therefore, the pyrogenic factor leading to the irreversible loss of Sphagnum cover inflicts a serious damage to the biosphere.

The research on the effects of fires on the mire vegetation cover is very important. Numerous publications are devoted to this topic (e.g. Efremova \& Efremov, 1994; Zoltai et al., 1998; Vom- persky et al., 2007; Benscoter \& Wieder, 2003). Peat fires make a substantial contribution to global greenhouse gas emissions, thus directly affecting the climate. Post-pyrogenic changes increase the drainage of peat and lead to the accumulation of combustible materials (dwarf shrubs). This increases the fire frequency (Furyaev et al., 2013), while a decrease in the moss productivity leads to a reduction in the rate of peat formation and longterm carbon accumulation (Turetsky et al., 2015).

The aim of this study was to establish the degree of vegetation cover transformation in the ecosystems of the Petrovskaya Pad' on the basis of geobotanical research and to compare it with the previously obtained data.

\section{Material and Methods}

The study area is located within $48.00-48.65^{\circ}$ $\mathrm{N}$ and $133.20-133.90^{\circ} \mathrm{E}$ in the southwestern part of the Middle Amur Lowland between the River Bira and the lower reaches of the River In with relative heights of $48-54 \mathrm{~m}$ (Fig. 1). The total area of Petrovskaya Pad' is about $20000 \mathrm{~km}^{2}$. According to climatic zoning, the territory belongs to the forest monsoon climatic zone of temperate latitudes. The harsh winter $\left(-16--23^{\circ} \mathrm{C}\right)$ with low snowfall lasts for 4.5 months. $80 \%$ of the annual precipitation occurs in the second half of the summer. The distribution of precipitation is very uneven from year to year as well.

To assess the degree of vegetation cover transformation in comparison with the period before intensive agricultural development that started in the early $20^{\text {th }}$ century, we used research data of botanists worked on the territory, which is now called the Jewish Autonomous Region. Korzhinsky (1892) was one of the earliest researchers of the vegetation in the region. In 1892, the author wrote that a specific feature of the plain territory here is «the vast waterlogged areas». Mainly forest ecosystems were studied previously in this territory (Rubtsova, 2017). During the Soviet period, the peat bogs were described in detail in the north of the Petrovskaya Pad' (Kats, 1929). Soviet botanists carried out geobotanical research here (Vasilyev, 1937). But the most detailed study of the territory was conducted by Kurentsova (1967) with the creation of a geobotanical map. According to the results of Kurentsova's geobotanical zoning, the area (then known as Petrovskaya Mar') has been named as the «lowland In-Bira region of waterlogged open larch forests combined with fens and wet Calamagrostis-Carex meadows». 


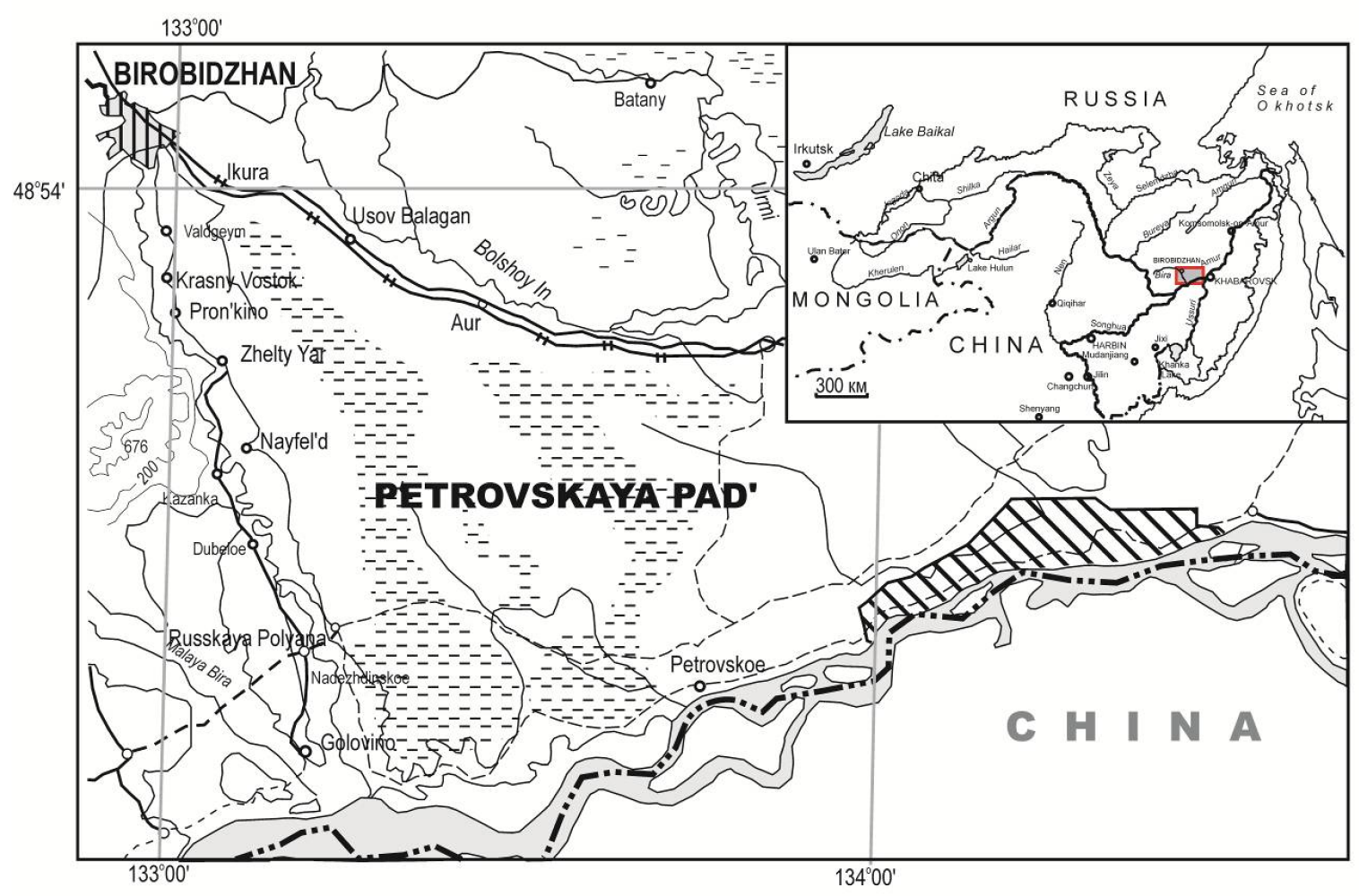

WIV - Cluster «Zabelovsky» of the Bastak State Nature Reserve

Fig. 1. The location of the Petrovskaya Pad' in the Russian Far East.

According to Kurentsova (1967), there are Sphagnum-dominated bogs and moss-Eriophorum and Carex mires, larch woodlands, which occupy more than $200 \mathrm{~km}^{2}$ in the valleys of many rivers in their middle reaches and on the interfluve of the River Amur and River In, in the lower reaches of the latter. The predominant vegetation of these mires consist of Sphagnum mosses. The mosses form a continuous carpet, although there are still small hollows in some places. The most common mosses are Sphagnum magellanicum Brid. and $S$. angustifollium (Warnst.) CEO Jensen. Near the water, the latter species is replaced by $S$. amblyphyllum (Russow) Warnst. (currently - S. flexuosum Dozy \& Molk). Sometimes, $S$. fuscum is found there. Kurentsova (1967) also provided the names of dominant vascular plant species, and thickness of deposit peat (from $30 \mathrm{~cm}$ to $1 \mathrm{~m}$ ) «composed of Sphagnum, herbs and dwarf shrubs».

In June 2009, a joint expedition was carried out. Its purpose was to create a buffer zone of the cluster area «Zabelovsky» (a cluster of the Bastak Reserve) within the area of Petrovskaya Pad'. It is of crucial importance for the biodiversity conservation and the maintenance of seasonal bird migration (Averin, 2009; Kalinin, 2009). Two transects of $70 \mathrm{~km}$ each crossing the Petrovskaya Pad' from northwest to southeast were made for that purpose. The main focus of the study was on phytocoenoses derived from mire communities in the course of post-fire succession. Sample plots of $10 \times 10 \mathrm{~m}^{2}$ were laid in the phytocoenoses of uniform floristic composition. We performed 26 geobotanical descriptions of the phytocoenoses according to the standard methods (Ipatov \& Mirin, 2008). We determined the boundaries of phytocoenoses, the species composition of vascular plants and mosses, the projective cover by species, their vitality, and the level of groundwater. Scientific names of plant species are given according to the Plant List (2013).

We collected peat samples from one deposit remaining after fires that is located $20 \mathrm{~m}$ from the shore of lake Krugloe. Drilling of the deposit to the mineral horizon was conducted using a Hiller drill. Peat samples were collected every $10 \mathrm{~cm}$. The identification of the species composition of the plant remnants and the determination of their percentage ratio in peat samples were carried out using a microscope (Kats et al., 1977). Unfortunately, we could not get peat samples from other deposits because of the widespread occurrence of seasonal frozen soil.

In addition, for the first time, we used the data of nine-year monitoring of re-vegetation of 
a mesotrophic dwarf shrub-Sphagnum bog in the south of the Middle Amur Lowland in the area of the settlement of Kiya $\left(47.89^{\circ} \mathrm{N}, 135.65^{\circ} \mathrm{E}\right)$. The description of this object and the methods for assessing the phytomass dynamics during the initial phase of post-pyrogenic recovery were published in Kopoteva \& Kuptsova (2016a).

\section{Results}

All sites of the Petrovskaya Pad' and adjacent territories were examined in detail during the expedition from 08 to 14 June 2009. Throughout most of the area the lack of water bodies and the degradation of wetlands were observed. The existing watercourses were experiencing a significant decrease in water level and were drying up. For example, the lakes of Petrovskaya Pad', Lake Krugloe, the lake in Petrunkin Sad, River Rassoshina, tributaries of River Petrovskaya have completely dried up. By the time of the survey, Petrovskaya Pad' was a plain area with hollows from former watercourses and dried-up oxbow lakes. It looked like a bare, drained, virtually lifeless, monotonous landscape.

Table 1 shows the species composition of described phytocoenoses that dominate there. It has extremely low projective cover (PC) of herbaceous plant species (e.g. plot 7: 48.44916 N 133.62972 E, and plot 18: $48.74861 \mathrm{~N} 133.37972 \mathrm{E}$ ). It is not typical for grass ecosystems of the Middle Amur Lowland (Kopoteva, 1993). We observed a low vitality of all species, apart from the dominant ones. The species diversity in the meadow phytocoenoses was significantly depleted (e.g. plot 3, groundwater level (GWL) at $-45 \mathrm{~cm})$. The former quaking mires (e.g., in the mire Molchanikha, east of the village of Nayfeld), severely burnt, had indicators of the recent fires and are characterised by areas covered by Carex pseudocuraica F. Schmidt, and Comarum palustre L. lied directly on the frozen soil (plot 20). The GWL measured in these former mires was $30-40 \mathrm{~cm}$ below the surface. The height of the burnt Comarum palustre individuals did not exceed $10-15 \mathrm{~cm}$. We noted a very low recovering of dominant plants and the introduction of non-typical species: Epilobium angustifolium L., Galium boreale L., Artemisia sp. In the central part of the Petrovskaya Pad' (near the Petrovskaya Sopka), we found areas of former bogs with burnt psychrophilic dwarf shrubs and remnants of Sphagnum hummocks. The projective cover of vascular plants (Carex sp.) did not exceed 10-20\%.

Table 1. Composition and distribution of species and ecological characteristics of phytocoenoses in state of pyrogenic subclimax

\begin{tabular}{|c|c|c|c|c|c|c|}
\hline \multirow{3}{*}{ Species } & \multicolumn{4}{|c|}{ Projective cover (PC) at sampling plots, $\%$} & \multirow{2}{*}{\multicolumn{2}{|c|}{$\begin{array}{l}\text { Species indices according to } \\
\text { Ramensky's ecological scales } \\
\text { (Seledets, 2011) }\end{array}$}} \\
\hline & \multirow{2}{*}{$\begin{array}{c}1-3,8-11 \\
14,16,17 \\
23-25^{*}\end{array}$} & \multirow{2}{*}{$\begin{array}{c}4-7,19 \\
21\end{array}$} & \multirow{2}{*}{$\begin{array}{c}13,15,18, \\
19,22\end{array}$} & \multirow[t]{2}{*}{$12,20,26$} & & \\
\hline & & & & & humidity & trophicity \\
\hline Anemonidium dichotomum Á. Löve \& D. Löve & 1 & & & & $57-89$ & $7-14$ \\
\hline Artemisia sp. & & & & 1 & - & - \\
\hline Calamagrostis epigeios (L.) Roth. & 1 & & & & $45-80$ & $6-15$ \\
\hline C. langsdorffii (Link) Trin. & 20 & $10-25$ & & & $54-97$ & $4-15$ \\
\hline C. stricta (Timm) Koeler & & 1 & 1 & & $61-105$ & $3-15$ \\
\hline Carex appendiculata (Trautv.et Mey.) Kuk. & 3 & & 7 & & $61-99$ & $6-14$ \\
\hline C. lasiocarpa Ehrh. & 2 & $10-20$ & & & $61-104$ & $4-13$ \\
\hline C. meyeriana Kunth. & & 5 & & & $58-100$ & $5-12$ \\
\hline C. pseudocuraica F. Schmidt & & $15-30$ & 5 & 15 & $66-101$ & $6-14$ \\
\hline C. schmidttii Meinsh. & & & 5 & & $56-97$ & $5-14$ \\
\hline Caltha palustris var. membranacea Turcz. & & 1 & 1 & & $63-85$ & $8-11$ \\
\hline Comarum palustre L. & & & $3-5$ & $30-60$ & $61-102$ & $4-13$ \\
\hline Epilobium angustifolium L. & & & & 1 & $52-94$ & $3-13$ \\
\hline Equisetum palustre L. & & & 1 & & $59-100$ & $4-15$ \\
\hline Galium boreale L. & & & & 1 & $50-94$ & $6-15$ \\
\hline Iris laevigata Fisch. & & & & 1 & $63-104$ & $4-13$ \\
\hline Lysimachia thyrsiflora $\mathrm{L}$. & & 1 & & & $61-104$ & $5-14$ \\
\hline Pedicularis grandiflora Fisch. & & & 1 & & $67-73$ & $5-6$ \\
\hline Ranunculus japonicus Thunb. & 1 & & & & $58-94$ & $8-13$ \\
\hline Salix myrtilloides L. & & 3 & 5 & & $61-98$ & $4-13$ \\
\hline Spiraea salicifolia L. & 1 & & & & $52-94$ & $4-14$ \\
\hline Thalictrum amurense Maxim. & 1 & & & & $60-75$ & $9-11$ \\
\hline PC of phytocoenosis & $20-30$ & $30-40$ & $20-30$ & $50-60$ & & \\
\hline
\end{tabular}

Note: *The descriptions were made in early June when many summer herbaceous species had not yet appeared. 
All these phytocoenoses are in the stage of the pyrogenic subclimax of the ecosystems. In other words, they are long-term communities supported by recurring fires (Neshataev, 2013).

An analysis of the trophic index of species (Table 1) shows that almost all the plants currently growing there can withstand very poor acidic soils. Species predominant here are oligomesotrophytes and ortho-mesotrophytes (Seledets, 2011). These species are indicators of soils forming under wetland phytocoenoses.

Throughout the entire plain area of Petrovskaya Pad', there is the unification of the vegetation cover described at the time by Vasiliev (1937) and Kurentsova (1967) as a multiplex landscape complex. In the second half of the 1960s, Kurentsova \& Opritova (1975) described the replacement of Sphagnum open larch forests by dwarf birch thickets («yerniki») as a result of recurring fires. By the time of our survey, the vegetation cover on $2 / 3$ of the area belonged to the meadow type and was dominated by Calamagrostis langsdorffi $i$ with a projective cover of 20-30\%, in some places $10-20 \%$ (Fig. 2). The rest of the open soil surface of meadows and fens, which is not occupied by vascular plants, is abundantly covered with fine brown mosses that serve as indicators of pyrogenic disorders: Ceratodon purpureus (Hedw.) Brid. and Cynodontium strumiferum (Hedw.) Lindb. Low hypsometric levels, such as hollows of former watercourses and dried-up oxbow lakes, are also occupied by fens with a very low projective cover. Some part of the typical species of the mires (e.g. Caltha palustris var. membranacea Turcz., Equisetum palustre L., Iris laevigata Fisch., Lysimachia thyrsiflora L.) have already disappeared. The rest of the species had a greatly reduced vitality. In some places, the surface of fens burnt up to ash-filled saucer-shaped depressions of up to $10 \mathrm{~cm}$ deep and 2-3 $\mathrm{m}$ in diameter with characteristic red traces of recent fires (Fig. 2 ). A complete absence of litter and dry grass typical for undisturbed grass mires of this region was also observed (Titlyanova et al., 1988).

The results of botanical analysis showed the presence of remnants of Sphagnum magellanicum (5\%) and Drepanocladus sp. (20\%), as well as Eriophorum sp. (15\%), shrub bark (Chamaedaphne caliculata (L.) Moench and Salix myrtilloides) and bark of Larix gmelinii (Rupr.) Kuzen. at a depth of 40-50 cm and lower in the samples from deposits of Carex-dominated fens (plot 18) located near Lake Krugloe (Fig. 3). Peat of 60-80 cm thick near the base of the deposit is composed mainly of Hypnales mosses such as Meesia triquetra (L. ex Jolycl.) Ångström and Drepanocladus sp. with a little admixture of Sphagnum magellanicum. This confirms that a mire developing processes characteristic for the Middle Amur Lowland unaffected by human activity prevailed here in the past. At a depth of $40-50 \mathrm{~cm}$ of the peat deposit, charcoal particles as traces (indicators) of past fires were observed. Alluvium (quartz) was found at the base of the peat deposit.

\section{Discussion}

The studies show that the amount of carbon stored in mineral soils is several times lower than in waterlogged soils, and it is an order of magnitude lower than in the mires (Minaeva et al., 2008). Mire and wetland habitats have much larger carbon reserves due to the presence of peat deposits. They function as a long-term reservoir of atmospheric carbon. That is what determines the main biospheric function of the mires.

Herbal ecosystems of the Middle Amur Lowland are highly productive and get burned quite often. Due to the very large above-ground and underground production, they have a peaty horizon of up to $30-40 \mathrm{~cm}$ and a thick litter of up to $10 \mathrm{~cm}$. The average annual stock of dried grass is $290 \mathrm{~g} / \mathrm{m}^{2}$, the litter is $530 \mathrm{~g} / \mathrm{m}^{2}$ (Titlyanova et al., 1988). The litter and dried grass recover within 2 years after the fire. Having lost them, the bare soil is exposed to deeper freezing at the conditions of severe winters in the Amur region. When measuring ground water levels during the expedition, in most places we found seasonal frozen soil at a depth of 5-10 $\mathrm{cm}$ from the surface.

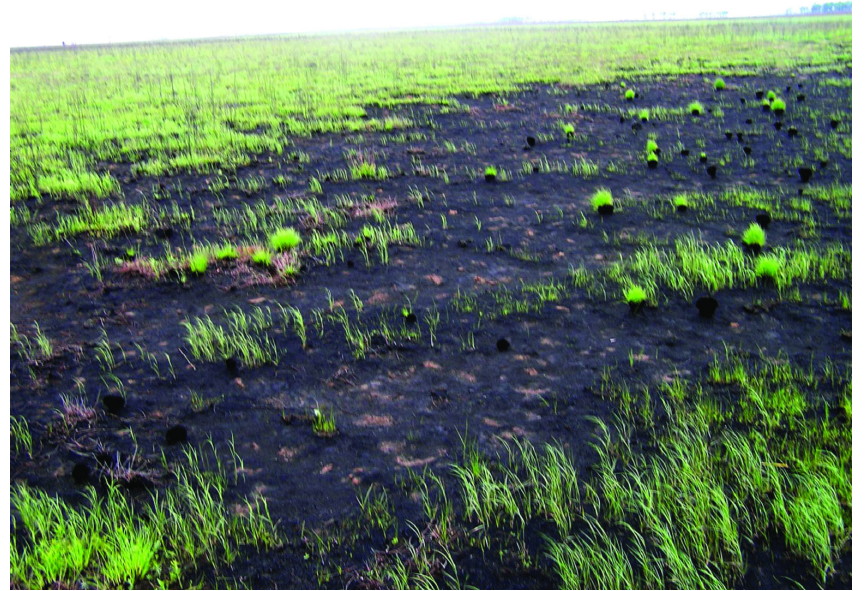

Fig. 2. Burnt grass fen, after the fire impact in May 2009. 


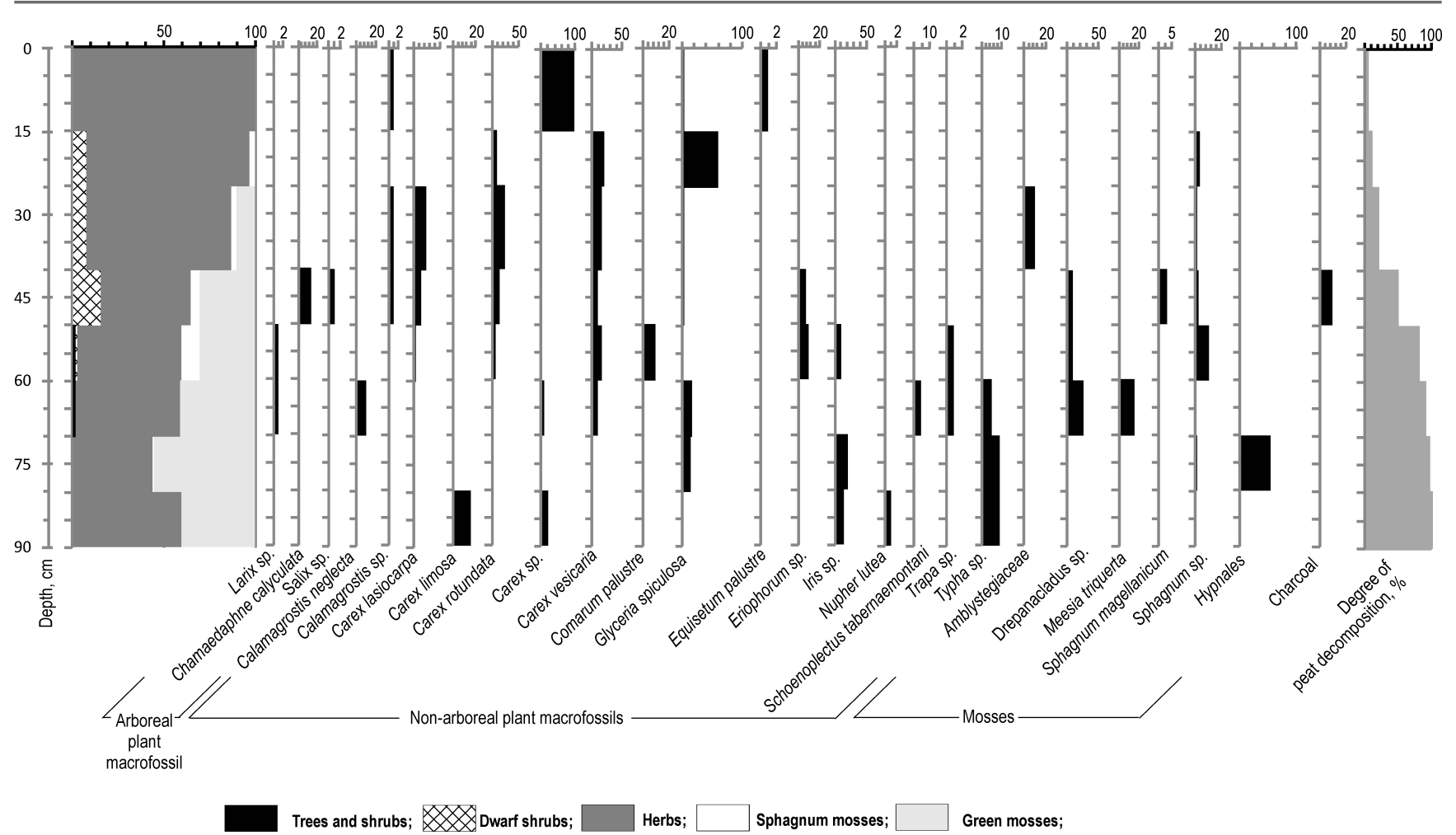

Fig. 3. Botanical composition of peat deposits of Carex fen in the vicinity of lake Krugloe.

Mesotrophic dwarf shrub-sphagnum larchwoods, the vegetation cover of which was described by Kurentsova (1967), in most cases have a peat deposit thickness of 50-80 cm here (Prozorov, 1985). They often burn as well, which is the topic of many publications. The deposits are composed mainly of fen and transitional peats. In particular, the peat of two-meter-deep deposit sampled in the Bastak reserve to the north of Petrovskaya Pad' is composed mainly of dwarf shrub-herbaceous lowland peat with admixture of Sphagnum mosses (Kopoteva, 2011). These mires have a much more complex structure than fens due to the symbiosis between Sphagnum mosses and psychrophilic shrubs. The unique structure of the vegetation cover of these mires can be preserved for a long period of time, since they are subclimax ecosystems (Popov, 2000). Under the continuous loose cover of living Sphagnum mosses $(5-7 \mathrm{~cm})$, an acrotelm of $30-35 \mathrm{~cm}$ thickness is located. It is an aerated horizon where the main processes of organic decomposition take place and peat formation begins.

In the course of the post-pyrogenic restoration of vegetation on mesotrophic mires, herbaceous plants and dwarf shrubs are restored in the first place. As shown in the mires in the basin of the river Kiya, the restoration of sphagnum mosses under favorable humidification conditions begins only in the sixth year (Kopoteva \& Kuptsova, 2016b). Moreover, the process is affected by the succession of brown mosses, especially those of the genus Polytrichum. The latter were able to replace Sphagnum, displacing them for a while from previous habitats in areas undisturbed by fire. (Kopoteva, 2019). But according to our observations, the duration of Polytrichum succession is relatively short in contrast to the meso-oligotrophic hydroseries after the post-pyrogenic recovery of mires dominated by Sphagna (Popov, 2000). An oligotrophic Sphagnum cover is generally a cyclic succession that can exist for centuries (Kats, 1934). Fires do not only destroy the living moss cover, but also disturb the structure of the acrotelm. Our observations show that its recovery takes a much longer time than that of the structure of the aboveground phytomass. Fig. 4 shows the dynamics of the Sphagnum moss mortmass (without roots of vascular plants) in an acrotelm after the 2008 fire (Kopoteva \& Kuptsova, 2016a). An acrotelm of the bog area undisturbed by fire is mainly represented by a fraction of poorly decomposed tirr that consist of moss stems with admixture of peat. In the burnt area, the upper part of the acrotelm was destroyed by the fire. The soil there was represented by peat and more decomposed tirr (fragments of Sphagnum stems and branches of a darker colour). The average density of these three fractions over the years of research in the non-burnt area was 1.5-2 times lower $\left(2563.3 \pm 128.2 \mathrm{~g} / \mathrm{m}^{2}\right)$ than that on the burnt one $\left(4847 \pm 335.4 \mathrm{~g} / \mathrm{m}^{2}\right)$. 
(a)

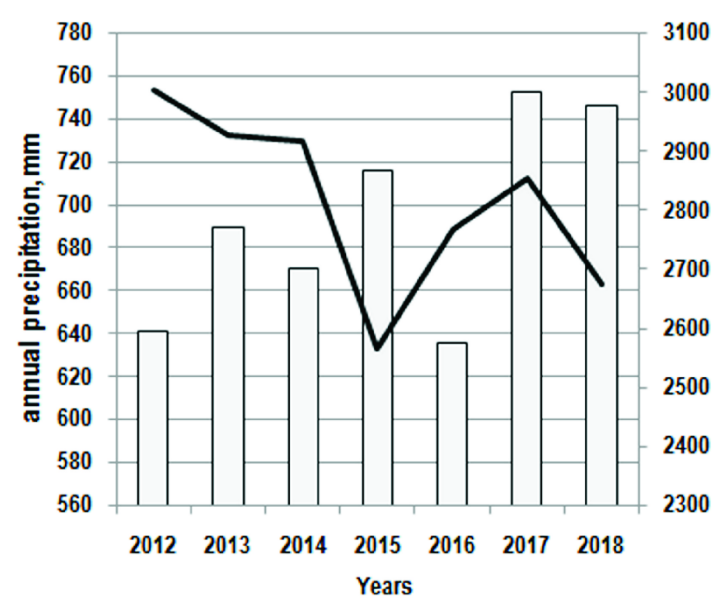

(c)

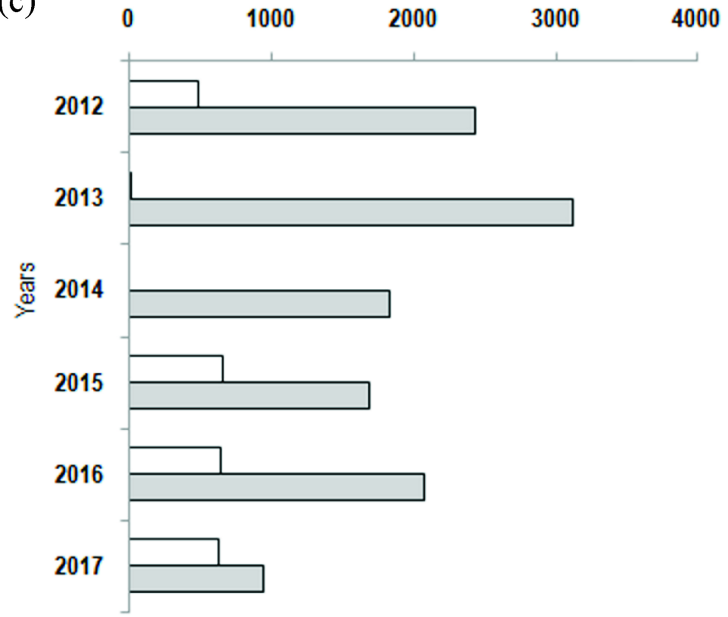

(b)

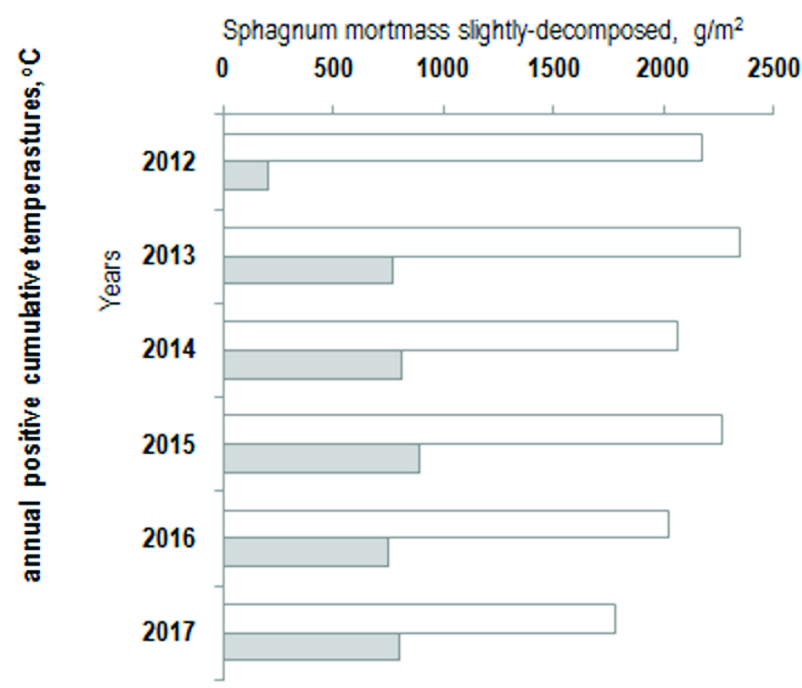

(d)

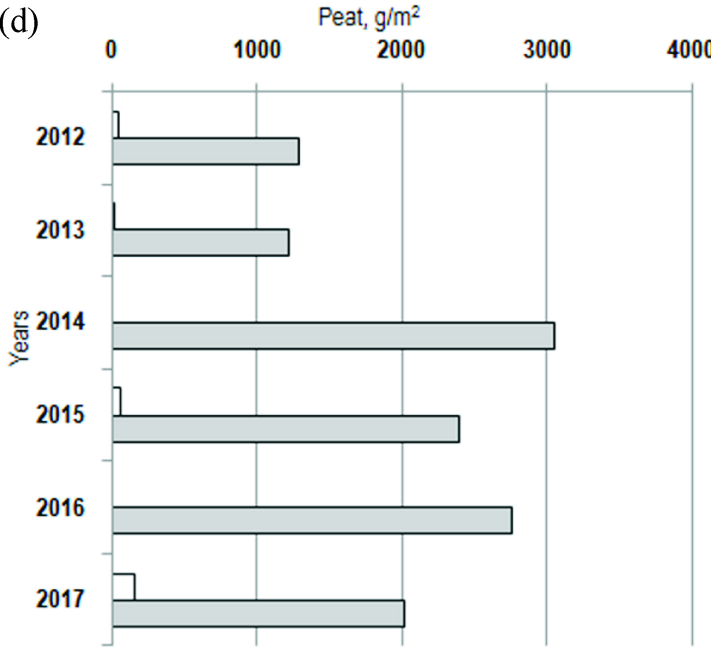

- undisturbed plot; - burned plot

Fig. 4. Dynamics of the sums of positive temperatures and precipitation (a); dynamics of tirr of a low (b) and a high (c) degree of decomposition and of peat (d) in a layer of $0-30 \mathrm{~cm}$ in the undisturbed and burnt areas of the bog in the vicinity of the Kiya settlement.

Previously, we estimated the burnt Sphagnum mortmass (of low decomposition degree in the horizon of $0-20 \mathrm{~cm}$ ) at $777 \pm 82 \mathrm{~g} / \mathrm{m}^{2}$ taking into account the mosaic pattern of the burning (Kopoteva \& Kuptsova, 2016 a). Comparing the difference of the values of this fraction in 2012 with the undisturbed and burnt parts of the mire, we obtain a similar value of $831.5 \pm 141.2 \mathrm{~g} / \mathrm{m}^{2}$.

The dynamics of the structure of the acrotelm on the undisturbed area is weakly expressed. In spring 2014, a fire did not touch the areas that were left unburnt in 2008. A reduction in the inflow of the tirr of a low degree of decomposition in 2017 can be explained by a rapid expansion of Polytrichum strictum that increased after the fire (Kopoteva, 2019). After 2014, the peat mass increased in samples from the burnt area. This is most likely due to an increase in the mosaicity of microtopography after the catastrophic fire in 2008. However, as we can see, due to the state of the acrotelm structure in 2017 , the process of its complete restoration would take a long time. It largely depends on the production of restored Sphagnum mosses.

Botanical analysis of peat acrotelm of the burnt area in 2012-2013 showed that it consists of Sphagnum remnants and dwarf shrubs (20$60 \%)$, as well as small bryophytes $(15-20 \%)$ and a small amount of Eriophorum. The further analysis showed an increasing number of remnants of dwarf shrubs, brown mosses and Eriophorum. The degree of peat decomposition was increasing. 
An analysis of the peat deposit stratigraphy at the Petrovskaya Pad' provides evidence that the direction of change of bog vegetation in the process of changes in the hydrological regime is typical of the Middle Amur Lowland. It is very likely that the formation of the mire has begun in the subatlantic period of the Holocene (Neishtadt, 1957; Khotinsky, 1977). The formation of peat-forming mires on the territory of Petrovskaya Pad' has begun after the cessation of the flood regime, which is evidenced by the presence of alluvium (quartz) and the change of priority in the composition of the vegetation from hydrophytes to hygrophytes. This is a classic change of an overgrown reservoir with a moss (in this case, Hypnum) mire.

The presence of the remnants of Sphagnum mosses, dwarf shrubs and larch bark in peat indicates the existence of mesotrophic shrub-Sphagnum larchwood at a certain stage of the mire-forming process. Mires of this type can be found in the environment of grassy ecosystems, which is confirmed by the data of Kurentsova (1967). We did not see them during the geobotanical survey of the modern vegetation cover of the Petrovskaya Pad'.

\section{Conclusions}

Thus, as a result of uncontrolled annual burning on the territory between the rivers Bira-In, In-Amur, a special dynamic state of ecosystems was formed. It is an example of a pyrogenic subclimax or a complex of secondary permanent associations developed as a result of recurring fires (Neshataev, 2013).

Moss-dominated ecosystems that are capable of taking up and storing large amounts of carbon have completely disappeared and probably will not recover. Their biodiversity has significantly decreased. With the disappearance of shrub-Sphagnum peat-forming ecosystems, the habitats of the species listed in the Red Data Book of the Jewish Autonomous Region (2006) have been greatly reduced in size. It concerns, for instance, the following species: Pogonia japonica Rchb.f., Spiranthes sinensis (Pers.) Ames, and other hygrophytes such as Parnassia palustris L., Menyanthes trifoliata L., Vaccinium microcarpum (Turcz. Ex Rupr.) Schmalh., and Vaccinium oxycoccos L., Comarum palustre, Lobelia sessilifolia Lamb. All species except the last one are medicinal plants (Rubtsova, 2017). The elimination of wetlands as well drying of fens and bogs on the territory of Petrovskaya Pad' led to a reduction in the number of species of wild animals and the destruction of places suitable for nesting of Ciconia boyciana Swinhoe, 1873. They are the wet- lands that influence the formation of climatic conditions in most of the region. They accumulate and store fresh water, maintain the level of groundwater, return oxygen to the atmosphere, provide the River Amur with clean water from the waterlogged floodplain. It is enough to say that only from the territory of the Jewish Autonomous Region some 5000 medium and small rivers supply clean water directly or through large tributaries into the River Amur. It is not an accident that the wetlands of the South of the Russian Far East, including the Jewish Autonomous Region, are in the Ramsar List of Wetlands of International Importance that contains only 35 sites from Russia. Ramsar Wetlands are those that need special protection and conservation.

In 2013, in the River Amur valley there was a flood which caused an enormous economic damage, but, according to local ecologists, it «revived the environment» of the Petrovskaya Pad'. The flooding brought high amounts of water to this dried-up territory, the area became saturated with water, and it began to gradually come to life, returning its former ecological value. According to the locals, the quaking mires where they used to harvest Comarum palustre began to recover. However, the restoration of the mires here is possible only if the control is established over the annual agricultural burning. The problem is that the burning is still turning into catastrophic fires destroying remnants of peat deposits throughout the territory of the Petrovskaya Pad'.

\section{Acknowledgements}

The authors are grateful to the administration of the Bastak State Nature Reserve, in particular to its director A.Yu. Kalinin, as well as to the senior researcher of the Institute for Complex Analysis of Regional Problems of Far Eastern Branch of RAS (ICARP FEB RAS), T.A. Rubtsova, for the opportunity to collect field material.

\section{References}

Averin A.A. 2009. Far Eastern Stork on the territory of Petrovskaya Mar'. In: Territorial studies: goals, results and prospects: Abstracts of the $V$ regional school-seminar for young scientists, graduate students and students. Birobidzhan: ICARP FEB RAS. P. 4-7. [In Russian]

Bazarova V.B., Klimin M.A., Kopoteva T.A. 2018. The Holocene dynamics of the East Asian monsoon in the Lower Amur Region. Geography and Natural Resources 3: 124-133. [In Russian]

Benscoter B.W, Wieder R K. 2003. Variability in organic matter lost by combustion in a boreal bog during the 2001 Chisholm fire. Canadian Journal of Forest Research 33(12): 2509-2513. DOI: 10.1139/x03-162 
Benscoter B.W., Vitt D.H. 2008. Spatial Patterns and Temporal Trajectories of the Bog Ground Layer Along a PostFire Chronosequence. Ecosystems 11(7): 1054-1064. DOI: $10.1007 / \mathrm{s} 10021-008-9178-4$

Burenina T.A. 2006. Changes in the stocks of aboveground phytomass and carbon emissions during fires on forestmire complexes of Sakhalin island. Bulletin of the NSC FEB RAS 2: 75-85. [In Russian]

Efremova T.T., Efremov S.P. 1994. Peat fires as an environmental factor in the development of forest-mire ecosystems. Russian Journal of Ecology 5-6: 27-34. [In Russian]

Furyaev V.V., Zablotsky V.I., Samsonenko S.D., Chernykh V.A. 2013. Spatio-temporal impact of fires on forestmire ecosystems of the West Siberian Plain. Siberian Journal of Ecology 2: 195-202. [In Russian]

Germanova N.I. 1983. Intensity of processes of mineralisation of plant residues - peat-forming peat bogs with different humidity. In: Bog Biogeocoenoses and Their Changes as a Result of Anthropogenic Impact. Leningrad: Nauka. 168 p. [In Russian]

Ipatov V.S., Mirin D.M. 2008. Phytocoenosis description: Methodical Recommendations. St. Petersburg: St. Petersburg State University. 71 p. [In Russian]

Kalinin A.Yu. 2009. Optimisation of the Protected Areas Network in the Jewish Autonomous Region. PhD Thesis abstract. Vladivostok. 23 p. [In Russian]

Kats N.Ya. 1929. Mires of the Birobidzhan District of the Far Eastern Territory. Melioration and Peat 1: 48-54. [In Russian]

Kats N.Ya. 1934. On the study of the structure and methods of the peat-bedding layer. Peat Business 1: 35 40. [In Russian]

Kats N.Ya., Kats S.V., Skobeeva N.I. 1977. Atlas of Plant Residues in Peat. Moscow: Nedra. 371 p. [In Russian]

Khotinsky N.A. 1977. Holocene, Northern Eurasia. Moscow: Nauka. 200 p. [In Russian]

Knorre A.A., Kirdyanov A.V., Vaganov E.A. 2007. Variability of the annual production of above-ground phytomass of the main dominants in the high-latitude communities of Central Siberia. Rastitelnye Resursy 43(1): 3-15. [In Russian]

Kopoteva T.A. 1993. The structure of plant matter and the dynamics of the production processes of the bogs in the Middle Amur Lowland. PhD Thesis Abstract. Vladivostok. 16 p. [In Russian]

Kopoteva, T.A., Kuptsova V.A. 2016a. Effect of fires on the functioning of phytocenoses of peat bogs in the Middle-Amur Lowland. Russian Journal of Ecology 47(1): 11-18. DOI: 10.1134/S1067413615060089

Kopoteva T.A., Kuptsova V.A. 2016b. Effect of fires on phytomass and primary production dynamics of the mesotrophic undershrub-sphagnum bog in the Amur region. Zhurnal Obshchei Biologii 77(5): 397-405. [In Russian]

Kopoteva T.A. 1999. Pyrogenic factor and vegetation dynamics in the marshes of the Amur region. In: Peatlands and Paludified Forests in the Light of Issues of Sustainable Environmental Management. Moscow: GEOS. P. 58-61. [In Russian]
Kopoteva T.A. 2011. Role of fires in the peat deposits formation and dynamics of phytomass and production during postpirogenic period on mesotrophic shrub-sphagnum bogs of the Middle Amur lowland. In: Carbon Pools and Fluxes in Boreal Forest and Peatland Ecosystems. Syktyvkar: Komi Scientific Center, Ural Branch of RAS. P. 58-59. [In Russian]

Kopoteva T.A. 2019. Pecularities of the moss cover restoring after a catastrophic fire on the Priamurye' peatlands. In: Proceedings of the Conference «X meeting in memorandum of E.A. Galkina». St. Petersburg: Publishing House of St. Petersburg State Electrotechnical University «LETI». P. 97-99. [In Russian]

Korzhinsky S.I. 1892. Report on the research of the Amur Region as an agricultural colony. News of the East Siberian Department of the Imperial Russian Geographical Society 23(4): 73-138. [In Russian]

Kosykh N.P., Mironycheva-Tokareva N.P., Parshina E.K. 2009. Phytomass, production and decomposition of plant residues in the oligotrophic bogs of the middle taiga of Western Siberia. Tomsk State Pedagogical University Bulletin 81(3): 63-69. [In Russian]

Kozlovskaya L.S., Medvedeva V.M., Pyavchenko N.I. 1978. Dynamics of Organic Matter in the Process of Peat Formation. Leningrad: Nauka. 173 p. [In Russian]

Kurentsova G.E. 1967. Essay on the Vegetation of the Jewish Autonomous Region. Vladivostok: Far Eastern Book Publishing House. 62 p. [In Russian]

Kurentsova G.E., Opritova R.V. 1975. Anthropogenic changes of vegetation and the water regime of rivers in Primorye and the South Amur region. In: $B i$ ological Studies in the Far East. Vladivostok: Far Eastern Scientific Center of AS USSR. P. 32-37. [In Russian]

Minaeva T.Yu., Trofimov S.Ya., Chichagova O.A., Dorofeeva E.I., Sirin A.A., Glushkov I.V., Mikhailov N.D., Kromer B. 2008. Carbon accumulation in soils of forest and bog ecosystems of Southern Valdai in the Holocene. Biology Bulletin 35(5): 516-524. DOI: 10.1134/ S1062359008050142

Neishtadt M.I. 1957. The history of forests and the paleogeography of the USSR in the Holocene. Moscow: AS USSR. 403 p. [In Russian]

Neshataev V.Yu. 2013. Anthropogenic dynamics of taiga vegetation in European Russia. Dr.Sc. Thesis abstract. St. Petersburg. 42 p. [In Russian]

Popov S.Yu. 2000. Pyrogenic succession of sphagnum mosses in Central Russia. Botanicheskiy Zhurnal 85(2): 8996. [In Russian]

Prozorov Yu.S. 1985. Patterns of Development, Classification and Use of Mire Biogeocoenoses. Moscow: Nauka. 209 p. [In Russian]

Prozorov Yu.S., Anisimov V.M., Popov O.S. 1970. Bogs and their regime. In: Resources of the Surface Waters of the USSR. Vol. 18(Far East), issue 2(Lower Amur). P. 454475. [In Russian]

Pyavchenko N.I. 1967. On the productivity of the mires of Western Siberia. Rastitelnye Resursy 3: 523-533. [In Russian] 
Red Data Book of the Jewish Autonomous Region. Rare and Endangered Species of Plants and Mushrooms. Novosibirsk: «ARTA» Publishing House, 2006. 248 p. [In Russian]

Rochefort L., Vitt D.H., Bayley S.E. 1990. Growth, production and decomposition dynamics of Sphagnum under natural and experimentally acidified conditions. Ecology 71(5): 1986-2000. DOI: 10.2307/1937607

Rubtsova T.A. 2017. Flora of the Jewish Autonomous Region. Khabarovsk: Antar. 241 p. [In Russian]

Seledets V.P. 2011. Ecological assessment of the territory of the Far East of Russia by vegetation cover. Vladivostok: Dal'nauka. P. 388. [In Russian]

The Plant List. 2013. The Plant List. Version 1.1. Available from http:// www.theplantlist.org/

These priceless mires. In: Birobidzhan Star. Available from http:// www.gazetaeao.ru/eti-bestsennye-bolota. [In Russian]

Titlyanova A.A., Bazilevich N.I., Snytko V.A., Dubynin S.S., Kopoteva T.A., Magomedova L.N., Mironycheva-Tokareva N.P., Nefedyeva L.G., Semenyuk N.V., Tishkov A.A., Ti Tran, Khakimzyanova F.I., Shatokhina N.G., Shmakova E.I. 1988. Biological Productivity of Grass Ecosystems. Geographical Patterns and Environmental Features. Novosibirsk: Nauka. 134 p. [In Russian]
Turetsky M.R., Benscoter B.W., Page S., Rein G., van der Werf G.R., Watts A. 2015. Global vulnerability of peatlands to fire and carbon loss. Nature Geoscience 8(1): 11-14. DOI: 10.1038/ngeo2325

Vasiliev V.N. 1937. Vegetation Cover of the Small Khingan. Moscow - Leningrad: Publishing House of AS USSR. P. 103-272. [In Russian]

Vishnyakova E.K., Mironycheva-Tokareva N.P., Kosykh N.P. 2012. Dynamics of plant decompositions in the Vasyugan bogs. Tomsk State Pedagogical University Bulletin 7: 87-93. [In Russian]

Vitt D.H. 2000. Peatlands: ecosystems dominated by bryophytes. In: A.J. Shaw, B. Goffinet (Eds.): Bryophyte Biology. Cambridge: Cambridge University Press. P. 312-343.

Vompersky S.E., Glukhova T.V., Smagina T.V., Kovalev A.G. 2007. Conditions and consequences of pine forest fires on drained mires. Russian Journal of Forest Science 6: 35-44. [In Russian]

Zoltai S.C., Morrissey L.A., Livingston G.P., Groot W.J. 1998. Effects of fires on carbon cycling in North American boreal peatlands. Environmental Reviews 6(1): 13 24. DOI: 10.1139/a98-002

\title{
ПОСЛЕДСТВИЯ ПИРОГЕННОГО ФАКТОРА ДЛЯ ВОДНО-БОЛОТНЫХ УГОДИЙ ПЕТРОВСКОЙ ПАДИ (ЕВРЕЙСКАЯ АВТОНОМНАЯ ОБЛАСТЬ, РОССИЯ)
}

\author{
Т. А. Копотева, В. А. Купцова \\ Институт водных и экологических проблем ДВО РАН, Россия \\ e-mail:kopoteva@ivep.as.khb.ru,victoria@ivep.as.khb.ru
}

\begin{abstract}
В последние десятилетия по периферии заповедника Бастак в урочище Петровская падь сложилась тяжелая пирогенная обстановка, угрожающая территории заповедника. По материалам геоботанического обследования Петровской пади, сделанного в ходе совместной экспедиции в 2009 г., дается оценка современного состояния растительного покрова и постпирогенных изменений. В настоящее время этот район Среднеамурской низменности является ярким примером деградации водно-болотных угодий (ВБУ) в результате многократного воздействия палов, применяющихся в Приамурье населением и работниками сельского хозяйства. Отмечено широкое распространение процесса ксеризации растительности травяных болот изза резкого снижения уровня грунтовых вод. Проанализированы материалы предыдущих исследователей, которые привели к выводу, что из растительного покрова территории полностью исчезли мезотрофные кустарничково-сфагновые болота, ранее описывавшиеся Г. Э. Куренцовой. Их деградация объясняется авторами постоянно действующим пирогенным фактором. Впервые приводятся данные динамики структуры акротельма в постпирогенный период, полученные в ходе девятилетнего мониторинга. Глубокие изменения в структуре акротельма приводят к тому, что восстановление мезотрофных болот занимает десятки лет.
\end{abstract}

Ключевые слова: акротельм, биоразнообразие, болота, неконтролируемые палы, пирогенный субклимакс 